\title{
Effect of anticaking agents on caking and quality characteristics of garlic cream powder sauce
}

\author{
Jiyoon Kim ${ }^{1}$, Ji-Young Choi ${ }^{1}$, Jungsoo Kim ${ }^{1}$, Saeul Jeong ${ }^{1}$, Si-Hyeon Lee ${ }^{1}$, \\ Yujin $\mathrm{Oh}^{1}$, Kwang-Deog Moon ${ }^{1,2 *}$ \\ ${ }^{1}$ School of Food Science and Technology, Kyungpook National University, Daegu 41566, Korea \\ ${ }^{2}$ Food and Bio-industry Research Instiute, Kyungpook National University, Daegu 41566, Korea
}

\section{Anticaking agents 처리가 마늘크림분말 소스의 caking 형성 및 품질 특성에 미치는 영향}

\author{
김지윤 ${ }^{1} \cdot$ 최지영 $^{1} \cdot$ 김정수 $^{1} \cdot$ 정새울 $^{1} \cdot$ 이시현 $^{1} \cdot$ 오유진 $^{1} \cdot$ 문광덕 $^{1,2 *}$ \\ 1경북대학교 식품공학부 식품생물공학전공, ${ }^{2}$ 경북대학교 식품생물산업연구소
}

\begin{abstract}
The caking of powder sauce is a common problem during food processing and storage, and leads to critical issues in products quality. In this study, to address the problem of caking of garlic cream powder sauce, an optimal sauce mixing ratio was selected, and the quality characteristics was analyzed. Moisture content, hygroscopicity, and caking degree were the lowest with $2 \%$ silicon dioxide and $2 \%$ microcrystalline cellulose treatment $(\mathrm{S} 2 \mathrm{C} 2)$. In addition, the normalized turbidity and quality characteristics of the garlic cream powder sauce were improved. Anticaking agents (silicon dioxide and microcrystalline cellulose) did not significantly affect the sensory quality characteristics, such as viscosity, color value, flavor, and mouth-feel of the garlic cream powder sauce, and neither did they affect the consumer preference. Thus, it was concluded that $\mathrm{S2C2}$ treated with a combination of silicon dioxide and microcrystalline cellulose during long-term storage is the most effective in preventing caking and maintaining the quality characteristics. Upon examination with a usable range of food additives, it was found that it can also be used as a reference for a particular method for improving the food processing and preservation techniques in the powder sauce industry.
\end{abstract}

Key words : garlic, anticaking agent, silicon dioxide, microcrystalline cellulose, caking

\section{서 론}

마늘은 백합과(Lilliaceae) 파속(Allium)에 속하는 1년생 숙 근초 식물로서 원산지는 중앙아시아나 이집트로 추정되고 있 고, 한국에는 중국을 거쳐 전래되어 재배 역사도 매우 길다 (Kwon 등, 2003). 마늘은 특유한 맛과 향기성분 뿐만 아니라, 각종 생리활성 물질이 함유되어 있어 예로부터 우리나라 식
생활에서 필수적인 대표 조미료로 마늘 소비량의 $96 \%$ 는 가 정에서 양념, 소스로 애용되어 왔으며(Kang 등, 2014), 다양 한 식품 시장에서 그 영역을 넓혀가고 있다. 마늘은 수확 후 대부분 생마늘로 소비자에게 공급되고 있으나, 생마늘은 수 분이 많아 그 저장성이 약하며, 저장기간 중 발아, 발근 등으 로 인하여 품질 저하가 심하다(Kim 등, 2006). 마늘의 장기 저장 및 유통 중 발생하는 문제점을 개선하기 위해 건조 마늘

*Corresponding author. E-mail : kdmon@knu.ac.kr, Phone : +82-53-950-5773, Fax : +82-53-950-6772

Received 30 November 2020; Revised 14 January 2021; Accepted 25 January 2021.

Copyright (c) The Korean Society of Food Preservation.

This is an Open Access article distributed under the terms of the Creative Commons Attribution Non-Commercial License (http://creativecommons.org/licenses/by-nc/4.0) which permits unrestricted non-commercial use, distribution, and reproduction in any medium, provided the original work is properly cited. 
생산과 가공식품에 마늘 건조 분말의 이용이 증가되고 있다 (Kang 등, 2014). 마늘 건조 분말은 생마늘에 비해 풍미가 비 교적 온후하고 기능성 성분의 보유율이 높으며(Lee과 Koh, 1996), 편의성으로 인해 소비자들의 이용이 증가하고 있다.

하지만 이러한 다양한 이용에도 불구하고, 저장 및 유통 과정에서 문제점이 발생하는데, 그것은 바로 caking 현상이 다. 식품 분말의 고결 즉, caking 현상은 가공, 취급 및 보관 중에 발생하는 일반적인 문제이며, 제품 품질 및 기능 저하, 덩어리, 응집, 재수화 및 분산 불량, 관능 품질 저하 및 유통 기한 단축을 유발한다(Aguilera 등, 1995; Barbosa-Canovas 등, 2005). 분말 입자 표면에 wet surface가 발생하게 되고, 지속적인 흡착, 용해가 일어나면서 인근 분말입자들과 결합 하게 된다(Aguilera 등, 1995). 분말 caking의 주요 요인으로 는 당, 지방, 온도, 상대습도, 압력, 용해도, 입자분포 등이 있 다(Hartmann과 Palzer, 2011). 특히 분말소스의 원료로 마늘 이 이용되었을 때, 마늘은 농촌진흥청 농업기술길잡이 117 마늘재배편(RDA, 2017)에 따르면 $100 \mathrm{~g}$ 당 약 $9 \mathrm{~g}$ 의 당질을 함유하고 있어, 당의 흡습성으로 인해 유통 중 caking 현상이 발생하기 쉽다. 또한 마늘 분말 소스는 마늘 외에도 색, 감미 등을 위한 다양한 첨가물이 혼합되어 있으므로, caking이 발 생하게 된다. 식품 분말 caking에 대한 기존 연구로는 건조 방법과 온도 변화에 따른 감 분말의 흡습특성(Lee, 2001), 분 말양파의 갈변 및 caking 억제기술연구(Kim 등, 2008), 홍삼 의 지용성 성분을 이용한 발효홍삼 농축액 알갱이의 흡습방 지 효과(Shin, 2016) 등이 있다.

원료의 배합비, 제조 공정, 포장 방법, 유통 과정 등 다양한 변수를 통해서 분말의 caking이 발생할 수 있지만, 본 연구에 서는 anticaking agents의 첨가를 통해서 이를 조절하였다. Caking은 식품 분말의 응집 및 부착과 관련된 열화 현상이며 (Palzer과 Sommer, 2011), anticaking agents는 이러한 경향 을 감소시키는 식품 첨가물이다. 이러한 식품 첨가물은 대부 분의 나라에서 안전성을 고려하여 사용 용량의 범주를 정하 여 사용하고 있다. Anticaking agents로써 보편적으로 사용되 고 있는 이산화규소는 호흡기를 통해서 흡입 시 폐에서 미약한 독성작용이 관찰되었다는 보고(Cha 등, 2011)가 있으나, 현재 식품의약품안전처에서는 사용 기준을 총 중량의 $2 \%(\mathrm{w} / \mathrm{w})$ 이 하로 제한(MFDS, 2019)하고 있기 때문에 사용 용량의 범주 내에서는 문제가 없다. Lipasek 등(2012)의 연구에서도 powder blend에 anticaking agents의 최대 사용 수준을 $2 \%$ 이하로 선 정한 바를 확인할 수 있다. 또한 결정셀룰로스의 경우 분말의 안정성 및 고결방지의 목적으로 사용될 수 있으며, 무독성이 라는 특징이 있다(MFDS, 2019). 현재까지 anticaking agents 가 분말제품의 물리적 특성에 미치는 영향 및 흐름성 (flowability)을 증가시키는 방법에 관한 연구는 많이 보고되
어 있으나(Chang, 1996; Kee 등, 2000; Yi 등, 1998), 마늘이 함유된 분말스프의 caking 억제방법에 대한 연구는 미흡한 실 정이다. 따라서 본 연구에서는 마늘크림분말 소스의 caking화 에 대한 애로사항을 해결하기 위해, 먼저 anticaking agent 선 별 및 처리농도 탐색을 통한 마늘크림분말 소스의 최적 소스 배합비를 선정하고, 품질 특성에 미치는 영향에 대해 조사하 였다.

\section{재료 및 방법}

\section{실험재료}

마늘크림분말 소스의 주 원재료는 가당전지밀(식물성 크 림, 백설탕, 구연산삼나트륨, 유청분말 등), 탈지분유, 마늘 분말(동결건조 전처리), 휘핑크림 분말, 설탕, 소금, 쌀가루가 포함된 마늘 크림분말소스를 (주)영풍(Deagu, Korea)으로부터 제공받아 사용되었다. $\alpha$ 화 전분, 감자전분, 아세틸인산이전 분, 이산화규소, 결정셀룰로스는 (주)영풍에서 분말소스의 anticaking agents로 주로 사용하는 제품을 제공 받아 사용되 었다.

\section{Anticaking agent 처리}

마늘크림분말 소스에 $\alpha$ 화 전분, 감자전분, 아세틸인산이전 분, 이산화규소 및 결정셀룰로스를 각각 $2 \%$ 를 첨가하여 low density polyethylene(LDPE) 포장백에 담아 bag mixer를 이 용해 충분히 균질화 하였다. 그 후 caking 형성 억제 효과가

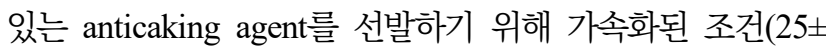
$\left.3{ }^{\circ} \mathrm{C}, 70 \pm 3 \% \mathrm{RH}\right)$ 에서 caking degree를 $\mathrm{Kim}$ 등(2008)의 방법 에 따라 측정하였다. 최종적인 배합비가 선정된 마늘크림분 말 소스는 균질화 후 완전히 밀폐하여 $10 \pm 3^{\circ} \mathrm{C}, 30 \pm 3 \% \mathrm{RH}$ 의 조건에서 5 일간 저장 후 품질 특성 분석을 수행하였으며, 별 도의 살균 및 건조 공정은 없었다.

\section{수분함량 측정}

마늘크림분말 소스는 식품공전 일반시험법의 건조감량법 을 사용하여 수분함량을 3 회 반복 분석하였다. $105^{\circ} \mathrm{C}$ 에서 5 시간 건조하여, 다음 식으로 계산 후 백분율로 나타내었다.

Moisture contents $(\%)=\left(\mathrm{w}_{0}-\mathrm{w}_{\mathrm{s}}\right) / \mathrm{w}_{0} \times 100$

$\mathrm{w}_{0}$ : 처음 시료 무게 $(\mathrm{g})$

$\mathrm{w}_{\mathrm{s}}$ : 건조 후 시료 무게 $(\mathrm{g})$

\section{흡습성 측정}

마늘크림분말 소스의 흡습성은 항량으로 맞춘 알루미늄 
접시에 시료 $5.00 \mathrm{~g}$ 을 담고 가속화된 조건으로 설정된 항온 항습기(JSRH-150CP, JS Research Inc., Gongju, Korea)에서 저장하면서 2 시간 간격 $(2,4,6,8)$ 으로 무게를 측정하여, 다 음 식으로 계산 후 백분율로 나타내었으며, 3 회 반복 측정되 었다.

$\operatorname{Hygroscopicity}(\%)=\left(\mathrm{w}_{0}-\mathrm{w}_{\mathrm{s}}\right) / \mathrm{w}_{0} \times 100$

$\mathrm{w}_{0}$ : 처음 시료 무게 $(\mathrm{g})$

$\mathrm{w}_{\mathrm{S}}$ : 저장 후 시료 무게 $(\mathrm{g})$

\section{미세구조 및 입도 분석}

마늘크림분말 소스의 미세 구조를 관찰하기 위하여 분말 약 $0.5 \mathrm{~g}$ 을 납/백금으로 160 초간 코팅하였다. SEM image는 주사전자현미경(SU8220, Hitachi, Tokyo, Japan)을 이용하여 가속전압 $5.0 \mathrm{kV}$ 에서 50 배율에서 분석하였다. 입도분석은 레이저 회절 원리를 이용한 입자 크기 분석기(Mastersizer 3000, Malvern, Kyoto, Japan)를 이용하였다. 측정영역은 0.1-3,500 $\mu \mathrm{m}$ 로 시료를 ethanol에 분산시켜 평균 입자 크기 (Mean particle diameter)를 분석하였다.

\section{Caking 분석}

마늘크림분말 소스의 caking 분석은 항량으로 맞춘 알루미 늄 접시에 시료 $10.00 \mathrm{~g}$ 을 담고 가속화된 조건으로 설정된 항온항습기(JSRH-150CP, JS Research Inc.)에서 1시간 간격 $(1,2,3)$ 으로 시료를 저장 후 350 mesh의 Tyler sieve로 2분 간 $200 \mathrm{rpm}$ 으로 진동시켜 sieve에 남아 있는 무게를 진동 전 무게로 나눈 후 5 회 반복 측정되었으며, 백분율로 나타내었 다.

Caking degree $(\%)=\left(\mathrm{w}_{0}-\mathrm{w}_{\mathrm{s}}\right) / \mathrm{w}_{0} \times 100$

$\mathrm{W}_{0}$ : 처음 시료 무게 $(\mathrm{g})$

$\mathrm{W}_{\mathrm{S}}$ : 진동 후 시료 무게 $(\mathrm{g})$

\section{분산성 측정}

마늘크림분말 소스의 분산성은 증류수 $100 \mathrm{~mL}$ 에 시료 $0.18 \mathrm{~g}$ 을 혼합한 후 UV-Vis spectrophotometer(optizenPOP, Mecasys Co., Ltd., Deagu, Korea)를 이용하여 1시간 간격으 로 9 시간 동안 $600 \mathrm{~nm}$ 에서 흡광도를 3 회 반복 측정하였으며, 측정값은 $\mathrm{ABS}$ 값으로 나타내었다.

\section{점도 측정}

마늘크림분말 소스의 점도는 점도계(DV1M, Brookfield
Engineering, MA, USA)를 이용하여 측정하였다. $95-100^{\circ} \mathrm{C}$ 증류수 $150 \mathrm{~mL}$ 에 분말 $60 \mathrm{~g}$ 을 분산시킨 후 소스가 $65^{\circ} \mathrm{C}$ 에 도달하면 회전속도 $50 \mathrm{rpm}$ 에서 spindle No.62을 사용하여 2 분간 작동시킨 후의 값을 3 회 반복 측정 후 평균값으로 나타 내었다.

\section{가용성고형분 및 $\mathrm{pH}$ 측정}

마늘크림분말 소스의 가용성고형분은 증류수 $10 \mathrm{~mL}$ 에 시 료 $10 \mathrm{~g}$ 을 혼합한 뒤 원심 분리하여 나온 상등액을 이용하여 측정하였다. $\mathrm{pH}$ 는 $\mathrm{pH}$ meter( $\mathrm{pH} 510$ benchtop meter, Oakton Instruments, Vernon Hills, IL, USA)로 측정하였으며, 가용성 고형분은 굴절 당도계(N2, Atago Co., Tokyo, Japan)로 측정 하고 단위는 ${ }^{\circ} \mathrm{Brix}$ 로 나타내었다. 모든 측정값은 3 회 반복 측 정되었다.

\section{색도 측정}

마늘크림분말 소스의 외관을 평가할 수 있는 색도는 백색 판 $\left(\mathrm{L}^{*}=97.79, \mathrm{a}^{*}=-0.38, \mathrm{~b}^{*}=2.05\right)$ 으로 보정된 colorimeter (CR-400, Konica Minolta Co., Osaka, Japan)로 5회 반복 측 정하였으며, 명도( $\left.\mathrm{L}^{*}=\mathrm{lightness}\right)$, 적색도( $\left.\mathrm{a}^{*}=\mathrm{redness}\right)$, 황색도 ( $\mathrm{b}^{*}=$ yellowness)로 나타냈다.

\section{관능검사}

관능검사는 훈련된 경북대학교 대학원생 13 명을 대상으로 실시하였으며, 크림맛, 마늘맛, 이취, 부드러운 정도, 종합적 기호도 항목으로 나누어 5 점 척도를 기준으로 절대평가 하도 록 하였다. 본 관능검사는 경북대학교 생명윤리심의위원회에 서 면제 승인을 받고 안전하게 진행하였다.

\section{통계분석}

실험은 3회 이상 반복 측정하여 평균과 표준편차로 표시하 였다. 또한 유의성 검정을 위해 SPSS software package (Version 25, SPS Inc., Chicago, IL, USA) 프로그램을 사용 하여 분산분석(ANOVA)을 실시하여 $\mathrm{p}<0.05$ 수준에서 처리 샘플 간 Duncan의 다중범위검정을 실시하였다.

\section{결과 및 고찰}

\section{Anticaking agent 선별 및 처리 농도}

분말 제품에 다양한 anticaking agent 처리가 덩어리 형성 을 억제하는 작용을 할 수 있다는 연구 결과(Kee 등, 2000; Meng 등, 2019; Wang과 Zhou, 2015)에 근거하여 $\alpha$ 화 전분, 감자전분, 아세틸인산이전분, 이산화규소 및 결정셀룰로스의 caking 형성 억제 효과를 측정한 결과는 Table 1과 같다. 모든 
Table 1. Effect of various anticaking agents on the degree of caking in garlic cream powder sauce

\begin{tabular}{|c|c|c|c|}
\hline \multirow{2}{*}{ Treatment $^{1)}$} & \multicolumn{3}{|c|}{ Caking degree $(\%)^{3)}$} \\
\hline & $1 \mathrm{~h}$ & $2 \mathrm{~h}$ & $3 \mathrm{~h}$ \\
\hline Control $^{2)}$ & $13.10 \pm 1.26^{4) \mathrm{ns} 5)}$ & $32.67 \pm 2.61^{\mathrm{ns}}$ & $87.30 \pm 0.34^{\mathrm{ab} 6)}$ \\
\hline Pregelatinized starch & $20.67 \pm 1.49^{\mathrm{ns}}$ & $17.30 \pm 1.82^{\mathrm{ns}}$ & $97.83 \pm 0.25^{\mathrm{a}}$ \\
\hline Potato starch & $14.07 \pm 0.61^{\mathrm{ns}}$ & $31.27 \pm 1.09^{\mathrm{ns}}$ & $85.30 \pm 0.33^{\mathrm{ab}}$ \\
\hline Acetylated distarch phosphate & $6.60 \pm 0.16^{\mathrm{ns}}$ & $17.17 \pm 0.50^{\mathrm{ns}}$ & $93.83 \pm 0.82^{\mathrm{a}}$ \\
\hline Silicon dioxide & $17.67 \pm 1.41^{\mathrm{ns}}$ & $28.53 \pm 2.88^{\mathrm{ns}}$ & $52.07 \pm 1.60^{\mathrm{c}}$ \\
\hline Microcrystalline cellulose & $10.47 \pm 1.02^{\mathrm{ns}}$ & $26.47 \pm 0.69^{\mathrm{ns}}$ & $68.43 \pm 1.65^{\mathrm{bc}}$ \\
\hline
\end{tabular}

${ }^{1)}$ Garlic cream powder sauces were treated to various anticaing agent. This treatments include shaking with $2 \%$ pregelatinized starch, $2 \%$ potato starch, $2 \%$ acetylated distarch phosphate, $2 \%$ silicon dioxide and $2 \%$ microcrystalline cellulose, respectively for $5 \mathrm{~min}$.

${ }^{2)}$ Control was without any treatments

${ }^{3)}$ Caking was measured by determining the wight fraction of the particles having the original size in samples using vibrator after samples had been subjected to accelerated caking condition $\left(27 \pm 3^{\circ} \mathrm{C}, 70 \pm 3 \% \mathrm{RH}\right.$ for $\left.1-3 \mathrm{~h}\right)$.

${ }^{4)}$ Values are mean $\pm \mathrm{SD}(\mathrm{n}=5)$.

5)ns No significant differentce.

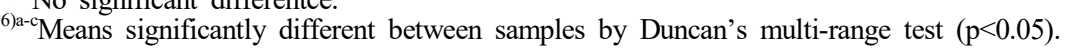

처리구 sample에서 저장 2시간까지 $17.17 \pm 0.05$ 에서 $31.27 \pm$ $1.09 \%$ 사이로 무처리구보다 caking 형성이 낮은 양상을 보 였으나, 샘플간의 유의적 차이는 확인할 수 없었다. 그러나 저장 3시간차에서는 이산화규소, 결정셀룰로스 처리 순으로 caking 형성 값이 낮은 것을 확인할 수 있다. 따라서 본 실험 에서는 마늘크림분말 소스의 anticaking agent로 이산화규소 와 결정셀룰로스를 선별하여 전처리를 진행하였다. 현재 식 품의약품안전처에서는 이산화규소의 사용 기준을 총 중량의 $2 \%(\mathrm{w} / \mathrm{w})$ 이하로 제한하고 있으며, 이산화규소의 경우 기술 적 효과를 달성하는데 필요한 최소량으로 사용하도록 권장하 고 있다(MFDS, 2019). 따라서 식품첨가물로서의 anticaking

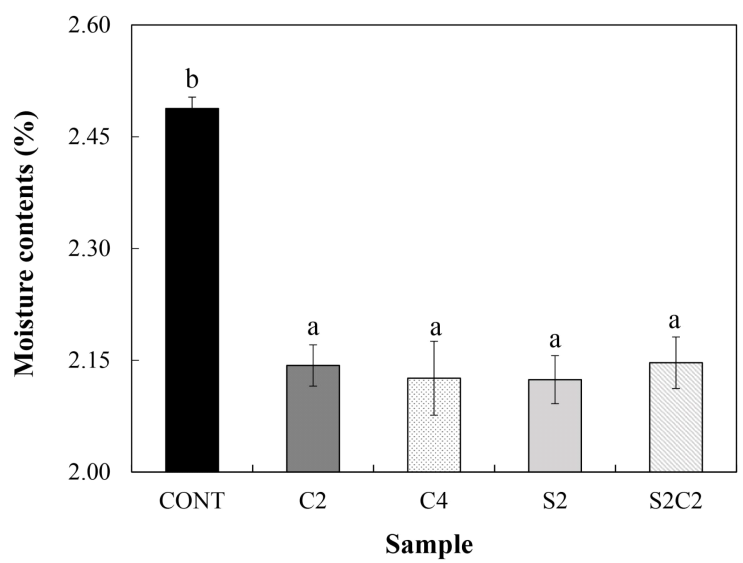

agent 사용 여부 및 기준을 고려하여 이산화규소의 경우 $2 \%$, 결정셀룰로스의 경우 $2-4 \%$ 로 처리농도를 결정하였다(Lipasek 등, 2012). 샘플은 어떠한 처리도 하지 않은 소스를 CONT, 전체 함량 대비 결정셀룰로스를 $2 \%$ 첨가한 것을 $\mathrm{C} 2$, 결정셀 룰로스를 $4 \%$ 첨가한 것을 $\mathrm{C} 4$, 이산화규소를 $2 \%$ 첨가한 것 을 S2, 결정셀룰로스 $2 \%$ 와 이산화규소 $2 \%$ 를 혼용 처리한 것 을 $\mathrm{S} 2 \mathrm{C} 2$ 로 명명한 후 추가적인 품질 특성을 분석하였다.

\section{수분함량 및 흡습성}

Anticaking agent의 처리 방법에 따른 마늘크림분말 소스 의 수분함량 및 흡습성 결과는 Fig. 1과 같다. 처리 방법에

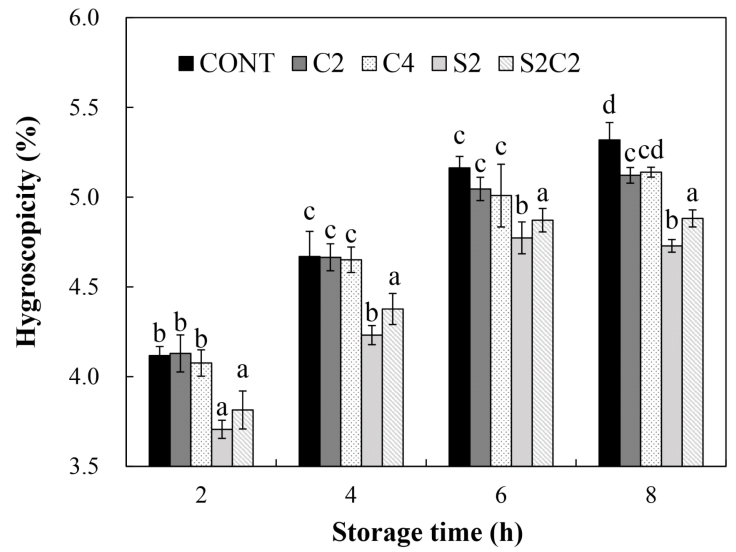

Fig. 1. Effect of anticaking agents on the moisture contents and hygroscopicity in garlic cream powder sauce.

CONT, no treatment; $\mathrm{C} 2$, treated with $2 \%$ microcrystalline cellulose; $\mathrm{C} 4$, treated with $4 \%$ microcrystalline cellulose; S2, treated with $2 \%$ silicon dioxide; S2C2, treated with $2 \%$ silicon dioxide $+2 \%$ microcrystalline cellulose.

Values are mean $\pm \mathrm{SD}(\mathrm{n}=3) .{ }^{\mathrm{a}-\mathrm{d}}$ Means significantly different between samples by Duncan's multi-range test $(\mathrm{p}<0.05)$. 
따라 수분함량은 유의적으로 다르게 나타났다. 특히 CONT 를 제외한 모든 처리구에서 수분 함량이 2.12 $\pm 0.03-2.15 \pm$ $0.03 \%$ 로 낮은 분포를 보였지만, 처리구 시료 간의 유의적 차 이는 확인할 수 없었다. Barbosa-Canovas 등(2005)에 따르면 anticaking agent의 메커니즘은 물과의 장벽으로서 작용하여 결정 성장을 억제하게 된다. 따라서 anticaking agent 처리를 통해 마늘크림분말 소스의 수분 함량 또한 낮게 나타난 것으 로 사료된다(Roge와 Mathlouthi, 2003).

흡습성의 경우, 식품 분말의 고결도와 같은 요인들에 영향 을 주는 인자이다(Wang과 Zhou, 2015). 흡습성은 온습도가 높은 가속화 조건에서 저장 시간이 경과할수록 증가하는 양 상을 보였다. 저장 시간이 8 시간 경과 후 모든 처리구 sample 에서 CONT보다 흡습성이 낮은 분포를 보이는 것을 확인할 수 있으며, 시료 간의 유의적 차이를 확인할 수 있다. 특히 $\mathrm{S} 2, \mathrm{~S} 2 \mathrm{C} 2$ 처리구에서 저장 시간 전반적으로 흡습성이 낮은 분포를 유지했으며, 이는 caking 형성 실험 결과와도 유사한 경향성을 보이는 것을 확인할 수 있다. 따라서 이산화규소와 결정셀룰로스를 병용 처리한 마늘크림분말 소스의 흡습성을 가장 낮추는 것으로 사료되며, 이는 caking 형성 방지에 중요 한 인자로 작용할 것으로 사료된다. 또한 Chung 등(2005)에 따르면 분말 식품의 흡습성은 저장 안정성과 관계가 있어 흡 습성이 크면 caking 현상의 발생이 촉진되어 저장 안정성이 낮아진다. 따라서 마늘크림분말 소스의 저장 안정성 확보를 위해서는 S2C2 처리가 필수적으로 요구된다.

\section{미세구조 및 입도특성}

전계방사형 주사현미경(SEM)을 이용하여 anticaking agent 의 함량 차이에 따른 마늘크림분말 소스의 미세구조를 확인 할 수 있었다(Fig. 2). 특히 가당전지밀, 탈지분유, 마늘분말, 휘핑크림분말, 설탕, 소금, 쌀가루 등으로 제조된 마늘크림분 말 소스의 경우 다양한 재료의 혼합으로 만들어진 분말이기 때문에 입자의 미세구조 분포가 균질하지 않은 것을 확인할 수 있으며, 시료에 처리된 재료의 형태학적 차이를 확인할 수 없었다. 그러나 평균적인 입자 크기 분포의 경우 결정셀룰로 스의 함량이 증가함에 따라 큰 입자가 많이 분포하는 것을 확인할 수 있었다.

이와 같은 결과는 입도 분석에서도 확인할 수 있었는데 (Fig. 2), 마늘크림분말 소스의 평균입자크기는 121-163 $\mu \mathrm{m}$ 로 구성되어 있으며, 특히 $\mathrm{C} 4$ 의 경우 입자 크기가 $156 \mu \mathrm{m}$ 인 $\mathrm{CONT}$ 에 비해 $163 \mu \mathrm{m}$ 로 크게 나타났다. 이를 통해 결정셀룰 로스의 입자 크기가 CONT에 비해 상대적으로 큰 것을 확인 할 수 있었다. 또한 $\mathrm{S} 2$ 와 $\mathrm{S} 2 \mathrm{C} 2$ 의 평균입자크기의 경우 121-124 $\mu \mathrm{m}$ 로 구성되어 있는 것을 통해 이산화규소의 입자 크기가 상대적으로 작은 것으로 사료된다. 이는 Carpin 등
CONT

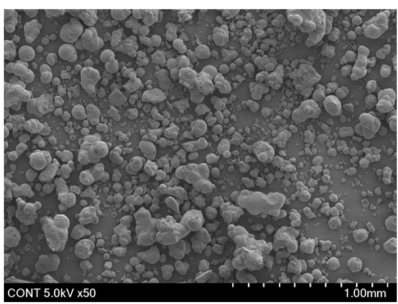

MPD: $156 \mu \mathrm{m}$
$\mathrm{C} 2$

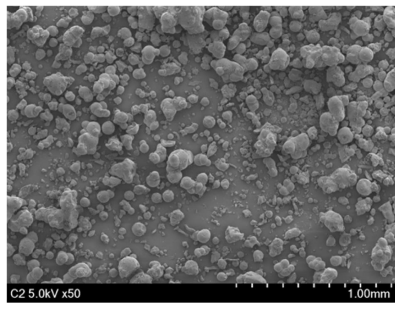

MPD: $152 \mu \mathrm{m}$

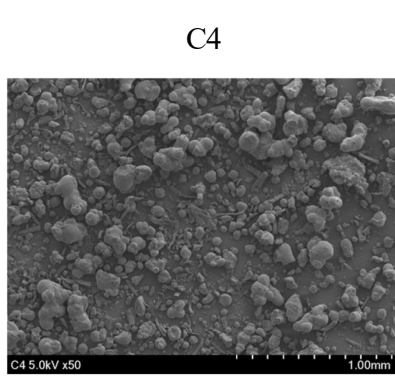

MPD: $163 \mu \mathrm{m}$
S2

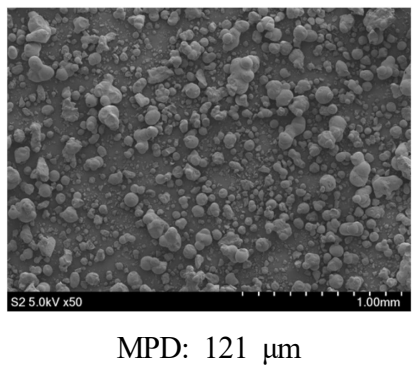

$\mathrm{S} 2 \mathrm{C} 2$

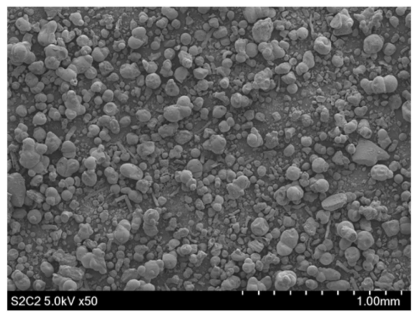

MPD: $124 \mu \mathrm{m}$
Fig. 2. Effect of anticaking agents on the scanning electron microscope photographs and particle size in garlic cream powder sauce.

CONT, no treatment; $\mathrm{C} 2$, treated with $2 \%$ microcrystalline cellulose; $\mathrm{C} 4$, treated with $4 \%$ microcrystalline cellulose; S2, treated with $2 \%$ silicon dioxide; S2C2, treated with $2 \%$ silicon dioxide $+2 \%$ microcrystalline cellulose.

MPD, mean particle diameter.

(2017)의 연구 결과와 유사한 것을 확인할 수 있었다.

\section{Caking 형성 및 분산성}

저장 유통 중 분말입자의 크기, 저장온도, 상대습도 등에 따 라 수분 흡습과 caking 현상이 나타나는데, 저장 수명(shelflife)을 단축시키는 원인이 된다(Kim 등, 2008). Anticaking agent의 처리 방법에 따른 마늘크림분말 소스의 caking 형성 및 분산성 결과는 Fig. 3 과 같다. 마늘크림분말 소스는 가속 화 조건에서 저장 시간이 증가할수록 급격하게 caking이 진 행되는 것을 확인할 수 있으며, 저장 초기에는 $\mathrm{C} 2, \mathrm{C} 4$ 처리 

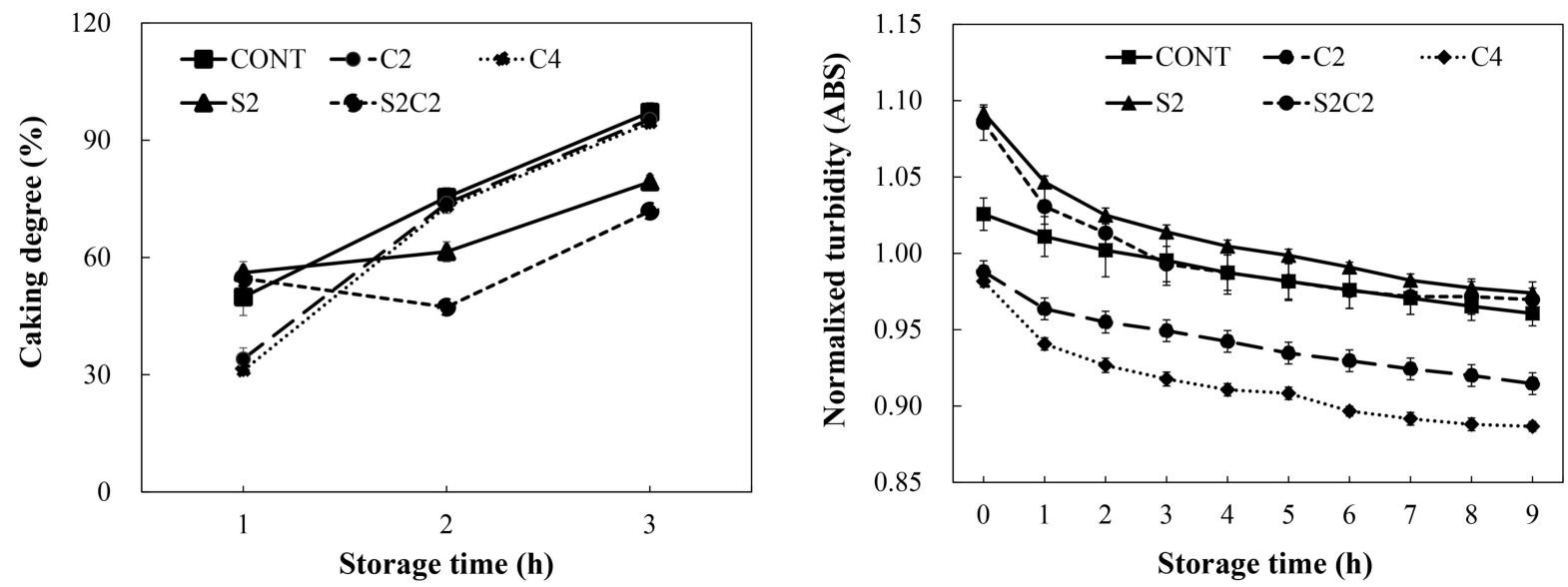

Fig. 3. Effect of anticaking agents on the caking degree and normalixed turbidity in garlic cream powder sauce.

CONT, no treatment; $\mathrm{C} 2$, treated with $2 \%$ microcrystalline cellulose; $\mathrm{C} 4$, treated with $4 \%$ microcrystalline cellulose; S2, treated with $2 \%$ silicon dioxide; S2C2, treated with $2 \%$ silicon dioxide $+2 \%$ microcrystalline cellulose.

Values are mean $\pm \operatorname{SD}(n=3)$.

구에서 caking 형성 정도가 낮은 양상이 나타났다. 그러나 저 장 2시간에서부터 $\mathrm{S} 2, \mathrm{~S} 2 \mathrm{C} 2$ 처리구의 경우 전반적으로 caking 형성이 낮은 양상을 보였으며, 저장 3시간에서는 $\mathrm{S} 2 \mathrm{C} 2$ 의 형성 율이 $71.87 \pm 1.26 \%$ 로 가장 낮았다. Caking 과정에서 유동적 인 분말 입자의 개체는 분말 간의 bridge 형성이 증가하며 덩 어리 형태로 변하게 되는데, 이는 분말 식품에 심각한 품질 문제로 발생하게 된다(Wang과 Zhou, 2015). 마늘크림분말 소스에 첨가된 당 성분은 흡습성이 강하기 때문에 대기 중의 수분을 흡습하여 수용성 성분을 용해하면서 입자 간의 부착 현상에 의해 caking을 형성한 것으로 사료되며, 이러한 현상 이 분말 제품의 유동성을 저해하게 된다. 그러나 온 · 습도가 높은 환경에서 식품의 입자가 서로 부착, 응집되는 경향을 감 소시키는 anticaking agent의 특성으로 인해 caking을 방지할 수 있었으며, 특히 S2C2 처리를 통해 저장 수명을 증가시킬 수 있을 것이라고 판단된다.

분산성은 오랫동안 침전 또는 부유 없이 수중에 균일하게 분산되는 특성으로 분산도가 높을수록 시간에 따른 혼탁도 변화가 적다(Park 등, 2018). 분산성이 높은 분말의 경우, 시 간 경과에 따른 혼탁도의 변화 정도가 적거나 느리게 진행되 며, 마늘크림분말 소스의 수중 분산도를 분석한 결과 모든 샘 플에서 저장 시간이 경과할수록 분산성이 낮아지는 것을 확 인할 수 있었다. $\mathrm{S} 2$ 와 $\mathrm{S} 2 \mathrm{C} 2$ 의 초기 분산성은 $1.086 \pm 0.004-$ $1.092 \pm 0.015 \%$ 로 높았으며 이는 이산화규소의 첨가를 통해 마늘크림분말이 수중에 고르게 분산되어 침전물 또는 부유물 발생이 줄어든 것으로 사료된다. 반면 $\mathrm{C} 2$ 와 $\mathrm{C} 4$ 의 초기 분산 성은 0.982 $\pm 0.015-0.988 \pm 0.019 \%$ 로 낮았다. 이는 평균입자크 기 분석 결과를 통해 상대적으로 입자 크기가 큰 결정셀룰로
스의 첨가가 마늘크림분말의 분산성 및 저장 시간에 따른 분 말의 침강 속도를 촉진시켰을 것으로 판단된다. Lee 등 (2015) 에 따르면 분산성이 낮은 분말은 시간에 따라 분말이 침강하 거나 부유하기 때문에, 층 분리가 생겨 결과적으로 시료의 혼 탁도가 작아지게 된다고 보고하고 있다. 따라서 $\mathrm{S} 2 \mathrm{C} 2$ 처리를 통해 분말의 품질 특성을 향상시킬 것으로 사료된다.

\section{점도, 가용성고형분, $\mathrm{pH}$ 및 색도}

점도, 가용성고형분, $\mathrm{pH}$, 색도는 크림스프의 품질 특성을 결 정하는 데 중요한 역할을 한다(Moon, 2013; Yang 등, 2014). Anticaking agent의 처리 방법에 따른 마늘크림분말 소스의 점도, 가용성고형분, $\mathrm{pH}$ 및 색도의 결과는 Table 2 와 같다. 수화하여 소스로 사용되는 마늘크림분말의 특성상 점도는 중 요한 품질 특성이며, 모든 샘플 간의 유의적 차이를 확인할 수 없었다. Anticaking agent로 사용된 이산화규소 및 결정셀 룰로스는 마늘크림분말 소스의 점도에 영향을 미치지 않아 관능적 특성에 영향을 미치지 않을 것으로 사료된다.

가용성 고형분 및 $\mathrm{pH}$ 의 경우 샘플 간의 유의적인 차이를 확 인할 수 있었다. 가용성 고형분의 경우 $46.27 \pm 0.46-47.87 \pm 0.31$ ${ }^{\circ} \mathrm{Brix}$ 로 이산화규소를 처리한 마늘크림분말 소스에서 비교적 높은 값을 나타내는 것을 확인하였다. 가용성 고형분은 수용 액 속에 녹아 있는 용질의 양을 \% 단위로 나타내는 단위로써 $\mathrm{S} 2 \mathrm{C} 2$ 처리 시 물에 녹는 용질의 양이 가장 많았고, 이를 통 해 분말 소스의 안전성 및 품질 특성을 향상시키는 것으로 사료된다. 이는 분산성 결과와도 유사한 경향을 보이는 것을 확인할 수 있다. $\mathrm{pH}$ 의 경우, 처리구 간의 눈에 띄는 경향성을 확인할 수 없었으며, anticaking agent가 제품의 산도에 영향 
Table 2. Effect of anticaking agents on the viscosity, total soluble solid, $\mathbf{p H}$ and color values (CIE $\left.\mathbf{L}^{*} \mathbf{a}^{*} \mathbf{b}^{*}\right)$ in garlic cream powder sauce

\begin{tabular}{|c|c|c|c|c|c|c|}
\hline & \multirow{2}{*}{$\begin{array}{l}\text { Viscosity } \\
\quad(\mathrm{cP})\end{array}$} & \multirow{2}{*}{$\begin{array}{c}\text { Total soluble solid } \\
\text { ( }{ }^{\circ} \text { Brix) }\end{array}$} & \multirow{2}{*}{$\mathrm{pH}$} & \multicolumn{3}{|c|}{ Color value } \\
\hline & & & & $\mathrm{L}^{*}$ & $a^{*}$ & $b^{*}$ \\
\hline $\mathrm{CONT}^{1)}$ & $5.20 \pm 0.692^{2 \text { ns } 3)}$ & $47.13 \pm 0.12^{\mathrm{b} 4)}$ & $6.50 \pm 0.01^{\mathrm{ab}}$ & $92.90 \pm 0.10^{\mathrm{a}}$ & $-1.87 \pm 0.06^{\mathrm{ab}}$ & $12.38 \pm 0.21^{\mathrm{d}}$ \\
\hline $\mathrm{C} 2$ & $6.40 \pm 1.93^{\mathrm{ns}}$ & $46.40 \pm 0.00^{\mathrm{a}}$ & $6.48 \pm 0.03^{\mathrm{ab}}$ & $93.17 \pm 0.03^{\mathrm{b}}$ & $-1.88 \pm 0.03^{\mathrm{ab}}$ & $12.21 \pm 0.03^{\mathrm{c}}$ \\
\hline $\mathrm{C} 4$ & $6.20 \pm 1.25^{\mathrm{ns}}$ & $46.27 \pm 0.46^{\mathrm{a}}$ & $6.47 \pm 0.01^{\mathrm{a}}$ & $93.27 \pm 0.10^{\mathrm{c}}$ & $-1.89 \pm 0.02^{\mathrm{a}}$ & $12.07 \pm 0.07^{\mathrm{c}}$ \\
\hline $\mathrm{S} 2$ & $5.00 \pm 0.35^{\mathrm{ns}}$ & $47.50 \pm 0.30^{\mathrm{bc}}$ & $6.51 \pm 0.02^{\mathrm{ab}}$ & $93.32 \pm 0.08^{\mathrm{cd}}$ & $-1.82 \pm 0.05^{\mathrm{bc}}$ & $11.75 \pm 0.14^{b}$ \\
\hline $\mathrm{S} 2 \mathrm{C} 2$ & $4.60 \pm 0.35^{\mathrm{ns}}$ & $47.87 \pm 0.31^{\mathrm{c}}$ & $6.52 \pm 0.04^{\mathrm{b}}$ & $93.38 \pm 0.05^{\mathrm{d}}$ & $-1.77 \pm 0.07^{\mathrm{c}}$ & $11.44 \pm 0.08^{\mathrm{a}}$ \\
\hline
\end{tabular}

${ }^{1)}$ CONT, no treatment; $\mathrm{C} 2$, treated with $2 \%$ microcrystalline cellulose; $\mathrm{C} 4$, treated with $4 \%$ microcrystalline cellulose; S2, treated with $2 \%$ silicon dioxide; S2C2, treated with $2 \%$ silicon dioxide $+2 \%$ microcrystalline cellulose.

${ }^{2)}$ Values are mean $\pm \mathrm{SD}(\mathrm{n}=3)$.

${ }^{3) n s}$ Means no significantly different.

${ }^{4) a-d}$ Means significantly different between samples by Duncan's multi-range test $(\mathrm{p}<0.05)$.

을 미치지 않아 관능적 특성 및 품질 안전성에도 영향이 없을 것으로 사료된다.

Anticaking agent의 처리 방법에 따른 마늘크림분말 소스 의 명도 $\left(\mathrm{L}^{*}\right)$, 적색도 $\left(\mathrm{a}^{*}\right)$, 황색도 $\left(\mathrm{b}^{*}\right)$ 값의 결과는 유의적인 차 이를 확인할 수 있었다. 모든 시료의 명도( $\left.\mathrm{L}^{*}\right)$ 값은 anticaking agent 함량이 증가할수록 유의적으로 증가했으며, $\mathrm{S} 2 \mathrm{C} 2$ 가 가장 높은 명도 값을 나타냈다. 황색도(b*)는 $\mathrm{S} 2$ 와 $\mathrm{S} 2 \mathrm{C} 2$ 가 $11.75 \pm 0.14$ 와 $11.44 \pm 0.08$ 로 비교적 낮은 값을 보였다. 이는 마늘크림분말 소스에 비해 백색의 색택을 가진 이산화규소 및 결정셀룰로스의 함량이 증가함에 따라서 마늘크림분말 소 스의 명도를 높이고, 황색도를 낮추었을 것으로 사료되며, 관 능적 특성에는 큰 영향이 없을 것으로 사료된다.

\section{관능평가}

Anti-caking agent의 처리 방법에 따른 마늘크림분말 소스 의 관능검사 결과는 Table 3 과 같다. 이취, 부드러운 정도 항 목은 모든 샘플에서 유사한 점수를 받았으며, 유의적 차이를
확인할 수 없었다. 이산화규소, 결정셀룰로스의 경우, 무색, 무취라는 특징(MFDS, 2019)이 있는데, 이러한 특징은 마늘 크림분말 소스의 인공적인 향 및 점도 등에 영향을 주지 않아 다음과 같은 관능적 특성 결과를 얻은 것으로 사료된다. 또한 크림맛이 강하게 느껴질수록, 마늘맛이 약하게 느껴지는 경향 이 있었으며, $\mathrm{C} 4$ 처리구에서 크림맛이 가장 높은 점수를 나타 냈다. 이는 결정셀룰로스의 첨가가 제품의 점도를 높인 것으 로 사료되며, 점도의 결과와 유사한 경향을 확인할 수 있다 (Choe 등, 2018). 종합적기호도 결과에서는 CONT에 비해 $\mathrm{C} 4$ 와 $\mathrm{S} 2 \mathrm{C} 2$ 처리가 높은 선호도를 보이는 것으로 나타났다. 결론적으로 이산화규소와 결정셀룰로스의 처리는 마늘크림 분말의 맛과 풍미에 큰 변화를 주지 않아 소비자의 기호도에 영향을 끼치지 않을 것으로 사료된다.

\section{요 약}

본 연구에서는 마늘을 바탕으로 한 크림분말의 caking화에

Table 3. Effect of anticaking agents on the sensory evaluation in garlic cream powder sauce

\begin{tabular}{cccccc}
\hline & Cream flavor & Garlic flavor & Off-odor & Mouth-feel & Overall acceptability \\
\hline $\mathrm{CONT}^{1)}$ & $3.92 \pm 0.86^{2 \mathrm{ab} 3)}$ & $3.15 \pm 1.07^{\mathrm{a}}$ & $1.23 \pm 0.60^{\mathrm{ns} 4)}$ & $4.38 \pm 0.51^{\mathrm{ns}}$ & $3.77 \pm 0.83^{\mathrm{a}}$ \\
$\mathrm{C} 2$ & $3.69 \pm 1.03^{\mathrm{ab}}$ & $3.69 \pm 1.18^{\mathrm{ab}}$ & $1.15 \pm 0.38^{\mathrm{ns}}$ & $4.23 \pm 0.73^{\mathrm{ns}}$ & $4.08 \pm 0.86^{\mathrm{ab}}$ \\
$\mathrm{C} 4$ & $4.38 \pm 0.65^{\mathrm{b}}$ & $2.85 \pm 0.90^{\mathrm{a}}$ & $1.23 \pm 0.44^{\mathrm{ns}}$ & $4.23 \pm 0.83^{\mathrm{ns}}$ & $4.38 \pm 0.77^{\mathrm{bc}}$ \\
$\mathrm{S} 2$ & $3.77 \pm 1.01^{\mathrm{ab}}$ & $3.31 \pm 1.03^{\mathrm{a}}$ & $1.15 \pm 0.38^{\mathrm{ns}}$ & $3.92 \pm 0.86^{\mathrm{ns}}$ & $3.69 \pm 0.48^{\mathrm{a}}$ \\
$\mathrm{S} 2 \mathrm{C} 2$ & $3.54 \pm 0.66^{\mathrm{a}}$ & $4.31 \pm 0.75^{\mathrm{b}}$ & $1.38 \pm 0.96^{\mathrm{ns}}$ & $3.92 \pm 0.64^{\mathrm{ns}}$ & $4.43 \pm 0.63^{\mathrm{bc}}$ \\
\hline
\end{tabular}

${ }^{1)} \mathrm{CONT}$, no treatment; $\mathrm{C} 2$, treated with $2 \%$ microcrystalline cellulose; $\mathrm{C} 4$, treated with $4 \%$ microcrystalline cellulose; S2, treated with $2 \%$ silicon dioxide; S2C2, treated with $2 \%$ silicon dioxide $+2 \%$ microcrystalline cellulose.

${ }^{2)}$ Values are mean \pm SD $(n=13)$.

3)a-c Means significantly different between samples by Duncan's multi-range test $(\mathrm{p}<0.05)$.

${ }^{4) \text { ns }}$ Means no significantly different. 
대한 문제를 해결하기 위해 최적 소스 배합비를 선정하고 그 품질 특성을 분석하였다. 다양한 anticaking agents 중 이산화 규소와 결정셀룰로스 처리를 통해 소스의 배합비를 구성하였 다. Anticaking agents 처리 시 분말 소스의 수분함량 및 흡습 도를 낮추는 것을 확인할 수 있었다. $\mathrm{C} 2$ 와 $\mathrm{C} 4$ 처리 시 저장 초기에 caking 정도를 감소시켰으나, 고온 다습한 환경에서 장 기적으로 저장 시 이산화규소, 결정셀룰로스를 병용처리한 $\mathrm{S} 2 \mathrm{C} 2$ 가 caking 방지에 가장 효과적이었다. 또한 $\mathrm{S} 2 \mathrm{C} 2$ 처리 시 caking 현상 방지뿐만 아니라, 분산성을 높여 마늘 크림분말소 스의 품질 특성을 향상시켰다. $\mathrm{S} 2 \mathrm{C} 2$ 처리는 마늘크림분말의 점도, 외관, 색과 맛, 풍미 등의 관능적 품질 특성에 큰 차이가 없어 소비자의 기호도에 영향을 미치지 않을 것으로 판단된 다. 결과적으로 장기적으로 저장 및 유통 시 이산화규소, 결정 셀룰로스를 병용처리한 $\mathrm{S} 2 \mathrm{C} 2$ 가 caking 방지 및 품질 특성 유 지에 가장 효과적이며, 저장 안전성 확보를 위해 방습 및 수 분 흡수제 봉입 포장 등 추가적인 연구가 요구된다.

\section{감사의 글}

본 연구는 농림축산식품부 농식품수출비지니스전략모델 구축사업의 의성마늘을 이용한 중국 수출용 고부가가치 소스 개발 과제(319087-03-1-CG000)에 의해 이루어진 것임.

\section{Conflict of interests}

The authors declare no potential conflict of interest.

\section{ORCID}

Jiyoon Kim http://orcid.org/0000-0002-7995-360X

Kwang-Deog Moon http://orcid.org/0000-0001-5277-3345

\section{References}

Aguilera J, del Valle J, Karel M. Caking phenomena in amorphous food powders. Trends Food Sci Technol, 6, 149-155 (1995)

Barbosa-Canovas G, Ortega-Rivas C, Juliano P, Yan H. Food Powders: Physical Properties, Processing, and Functionality. Kluwer Academics/Plenum Publishers, NY, USA, p 93-123 (2005)

Carpin M, Bertelsen H, Dalberg A, Bech JK, Risbo J, Schuck P, Jeantet R. How does particle size influence caking in lactose powder?. J Food Eng, 209, 61-67 (2017)
Cha CN, Jung WC, Lee YE, Yoo CY. In vivo acute toxicity of silicon dioxide nanoparticle to mice after intraperitonial injection. J Food Hyg Saf, 26, 43-48 (2011)

Chang KS, Kim DW, Kim SS. Bulk flow properties of selected food powders at different water activity levels. Food Sci Biotechnol, 5, 76-84 (1996)

Choe D, Kim YM, Nam JE, Nam K, Shin CS, Roh YH. Synthesis of high-strength microcrystalline cellulose hydrogel by viscosity adjustment. Carbohydr Polym, 180, 231-237 (2018)

Chung HS, Hong JH, Youn KS. Quality characteristics of granule prepared by protein-bound polysaccharide isolated from Agaricus blazei and selected forming agents. Korean J Food Preserv, 12, 247-251 (2005)

Hartmann M, Palzer S. Caking of amorphous powdersmaterial aspects, modelling and applications. Powder Technol, 206, 112-121 (2011)

Kee HJ, Jung ST, Park YK, Jung DO. Effects on anticaking of powdered onions by treatment of anticaking agents. Korean J Food Sci Technol, 32, 629-633 (2000)

Kim HS, Han MR, Chang MJ, Kim MH. Study of browning and caking reduction techniques in onion powder. Food Eng Prog, 12, 269-274 (2008)

Kim YP, Lee GW, Oh HI. Optimization of extraction conditions for garlic oleoresin and changes in the quality characteristics of oleoresin during storage. Korean J Food Nutr, 19, 219-226 (2006)

Kang JR, Kim GM, Hwang CR, Cho KM, Hwang CE, Kim JH, Kim JS, Shin JH. Changes in quality characteristics of soybean paste Doenjang with addition of garlic during fermentation. Korean J Food Cook Sci, 30, 435443 (2014)

Kwon SK. Organosulfur compounds from Allium sativum and physiological activities. J Appl Pharmacol, 11, 8-32 (2003)

Lee CM, Kim YE, Woo HD, Ko SH. Stability and sensory property of microencapsulated garlic powders. Food Eng Prog, 19, 291-297 (2015)

Lee JH, Koh HK. Drying characteristics of garlic. J Korean Soc Agric Mach, 21, 72-83 (1996)

Lee WY, Kim JK. Absorption characteristics of persimmon powder depending on temperature changes and drying methods. J East Asian Soc Dietary Life, 11, 479-484 (2001) 
Lipasek RA, Ortiz JC, Taylor LS, Mauer LJ. Effects of anticaking agents and storage conditions on the moisture sorption, caking, and flowability of deliquescent ingredients. Food Res Int, 45, 369-380 (2012)

Meng X, Ji J, Qi X, Nie X. Effect of anticaking agents on hardening and Maillard-induced protein aggregation in high-protein nutrition bars formulated with whey protein concentrate. LWT-Food Sci Technol, 108, 261-267 (2019)

Ministry of Food and Drug Safety. Korean Food Additives Code. MFDS. Cheongju, Korea, https://www.foodsafetyk orea.go.kr/portal/safefoodlife/foodAditive/foodAdditiveR vlv.do? (assessed October 2019)

Moon HS. Quality characteristics of cream soup with freeze-dried perilla leaf. J East Asian Soc Dietary Life, 23, 629-636 (2013)

Palzer S, Sommer K. Caking of water-soluble amorphous and crystalline food powders. In: Food Engineering Interfaces, Aguilera JM, Simpson R, Welti-Chanes J, BermudezAguirre D, Barbosa-Canovas G (Editor), Springer New York, NY, USA p 491-514 (2011)

Park JJ, Park DH, Lee JJ, Lee SY, Ibukunoluwa FO, Lee
WY. Absorption characteristics of black elephant garlic powder containing maltodextrin. Korean J Food Preserv, 25, 535-542 (2018)

Roge B, Mathlouthi M. Caking of white crystalline sugar. Int Sugar J, 105, 128-136 (2003)

Rural Development Administration. Garlic Cultivation Agricultural Technology Guide 117, RDA, Jeonju, Korea p 13 (2017)

Shin MG. Moisture adsorption preventative effect of fermented red ginseng extract spherical granules by using hydrophobic compounds. J Korean Soc Food Sci Nutr, 45, 1153-1161 (2016)

Wang W, Zhou W. Characterisation of spray dried soy sauce powders made by adding crystalline carbohydrates to drying carrier. Food Chem, 168, 417-422 (2015)

Yang SW, Kim BR, Lee JW, Lee C, Moon BK. Quality characteristics of cream soup with Hericium erinaceus powder. J East Asian Dietary Life, 24, 631-640 (2014)

Yi YS, Kang HH, Chang KS, Chang YI. Effect of some anticaking conditioners on the flowability of dried garlic powder. Korean J Food Sci Technol, 30, 1357-1361 (1998) 